\title{
Influence Hr Quality and Compensation to Performance Organization Through Motivation: A Case Study in Gatot Subroto Army Hospital
}

\author{
Andi Eko Prasetyo ${ }^{1 *}$, Abdul Rivai², Iwan Kurniawan Subagja ${ }^{3}$ \\ ${ }^{1}$ Student Master of Management, ${ }^{2}$ Associate Professor of Universitas Krisnadwipayana, ${ }^{3 L e c t u r e r ~ U n i v e r s i t a s ~ K r i s n a d w i p a y a n a ~}$ \\ Universitas Krisnadwipayana, PO BOX 7774 / Jat Cm Jakarta 13077 Indonesia
}

\section{*Corresponding Author}

Andi Eko Prasetyo

\section{Article History}

Received: 11.10.2019

Accepted: 18.10 .2019

Published: 02.11.2019

\begin{abstract}
This study aimed to analyze the influence of the quality of human resources and compensation to organizational performance through motivation. The study was conducted at Gatot Subroto Army Hospital with a number of samples are 133 people in the area of the organization. Sampling using a saturated sample. Analysis of data using path analysis. The results showed that the quality of human resources and compensation to organizational performance through motivation positive and significant impact.
\end{abstract}

Keywords: Quality of human resources, compensation, motivation, organizational performance.

\section{INTRODUCTION}

The quality of human resources is an important component of every movement development. Only qualified human resources to accelerate the higher the development of the nation. A large population, if not followed with adequate quality, will only be a burden development. Quality is a state resident population either individually or in groups based on the level of progress that has been achieved. Human resources in order to become a formidable resident must have adequate quality so that it can be an effective development capital. Without an increase in quality, large populations will cause various problems and the burden of development. The quality of human resources quality is often divided into physical and non-physical qualities.

Non-physical quality includes religious-spiritual quality, employee, work ethic, personality qualities of the society, and the quality of relationships in harmony with the environment. The quality of resources can affect the performance of the organization.the performance of the organization is generated by organizations that include results (outcomes) that the financial performance such as profit, as measured by return on assets, return on investment and so on, the performance of the market such as the expansion of market share, and sales. Besides the return of shareholders a return of shareholders and increase the economy of shareholders.

In some areas of the organization's performance can also be measured by other things such as strategic planning, operations, finance, legal and organizational development. In developing the institution or organization is a necessity to survive in the competitive world climate. Other factors that affect the performance of the organization is the compensation received by employees. All income in the form of money, goods directly or indirectly received by employees as a reward for services rendered to the company referred to as compensation. While understanding the compensation according to Simamora [1] is "What is accepted by the employees in exchange for their contributions to the organization. Arita [2] states compensation is all the income in the form of money or goods directly or indirectly received by employees in exchange for services provided to the agency. Compensation is everything received by employees as remuneration for their work or devotion. Factors that affect the compensation is productivity, ability to pay, willingness to pay, the supply and demand for labor, employee organizations and the rules and regulations. Motivation may also affect the performance of the organization, ability to pay, willingness to pay, the supply and demand for labor, employee organizations and the rules and regulations. Motivation is an impulse that will cause a person to perform an act in order to achieve certain goals. Motivation comes from the word motive which means "encouragement" or stimulation or "driving forces" that exist in a person.According to Elliot et al. [3], motivation is defined as an internal condition that raises us to act, encouraged us to reach certain goals, and keep us interested in a particular activity. According to Uno [4], the motivation can be defined as an internal and external impetus in a person who indicated the presence; desires and interests; encouragement and needs; hopes and ideals; awards and

Copyright @ 2019: This is an open-access article distributed under the terms of the Creative Commons Attribution license which permits unrestricted use, distribution, and reproduction in any medium for non commercial use (NonCommercial, or CC-BY-NC) provided the original author and source are credited. 
honors. Motivation is something that makes a person act [5] states that motivation is the impact of the interaction of a person with the situation [6]. Motivation is a force, energy, or power, or a complex situation and readiness within the individual to move towards a certain goal,

\section{LITERATURE REVIEW Quality Human Resources}

The quality of human resources is an important component of any development movement. Only qualified human resources to accelerate the higher the development of the nation. A large population, if not followed with adequate quality, will only be a burden development. Quality is a state resident population either individually or in groups based on the level of progress that has been achieved. Human resources in order to become a formidable resident must have adequate quality so that it can be an effective development capital. Without an increase in quality, the large population will give rise to various problems and the burden of development. Analysis of the quality of human resources quality is often divided into physical and non-physical qualities. Indicators that can describe the physical quality of the population include education level, health status, and quality of life index. Non-physical quality includes religious-spiritual quality, employee work ethic, personality qualities of the society, and the quality of relationships in harmony with the environment.

Sedarmayanti [7] suggested that quality is a measure that states how much had been filled with the requirements, specifications, and expectations. Nawawi [8] in that human resources are the people who work in an organization (also called personal labor, or employees) ". While Ndraha [9] says that the notion of quality human resources, namely: Human Resources quality is human resources capable of creating not only comparative value, but also the competitive value - generative - innovative by using the highest energy such as intelligence, creativity, and imagination, no longer solely use such coarse energy raw materials, land, water, energy, muscle, and so on.

Human resources $(\mathrm{HR})$ is one very important factor that can not even be released from an organization, whether institutional or company. SDM is also a key determinant of the company's development. In essence, the human form of a man employed as a driver in an organization to achieve the goals of the organization.

Today, the latest development saw employees not as a mere resource, but rather in the form of capital or assets to an institution or organization. Here SDM saw not just as a major asset, but an asset that is valuable and can be multiplied, developed (compare with the investment portfolio) and not vice versa as a liability (expense, cost). Here the perspective of human resources as an investment for the institution or organization is more prominent.

Understanding HR can be divided into two, namely micro and macro sense. Understanding HR Micro is an individual working and become a member of a company or institution and commonly referred to as servants, laborers, employees, workers, labor and others. HR macro sense is a resident of a country which has entered the age of the labor force, either has not worked as well as those already working. Broadly speaking, the notion of human resources is an individual who works as a driver of an organization, whether institutional or company and serves as an asset to be trained and developed abilities.

\section{Compensation}

Compensation according to Hasibuan [10] is: "All income in the form of money, goods directly or indirectly received by employees as a reward for services rendered to the company". While understanding the compensation according to Simamora [1] is: "What is accepted by the employees in exchange for their contributions to the organization. Arita [2] states compensation is all the income in the form of money or goods directly or indirectly received by employees in exchange for services provided to the agency.

Notoatmodjo [11] states that compensation is everything received by employees as remuneration for their work or devotion. Factors that affect the compensation is productivity, ability to pay, willingness to pay, the supply and demand for labor, employee organizations and the rules and regulations.

There are several things that can be used as an indicator of compensation, according to Simamora [1], these indicators are:

1) Wages and Salaries

Wages and salaries are different things. Wages are paid a base which is often used for production workers and maintenance or for daily workers who are not employees or full-time employees. Wages are usually is daily, weekly or monthly in accordance with an agreement between the employee and the employer. Salaries generally applicable to the fare paid weekly, monthly, or yearly given regularly.

2) Incentives

Is an additional incentive compensation above or beyond the salary or wages provided by the organization. Incentives are usually provided by the company on the basis of their job performance or productivity of employees. Achievement or productivity of employees with good work will receive incentives from the company.

3) Allowance 
Allowances are payments or services provided by the company as a protector or a complement to the basic salary. Examples of benefits are health and life insurance, vacation is borne by the company, pension programs, and other benefits related to the employment relationship.

4) Facility

Compensation in the form of facilities provided by the company to accelerate and simplify and motivate employees or employees in work. Examples are a pleasure facility/facilities such as a company car, club memberships, special parking places, or internet access, work uniforms, and so on.

\section{Motivation}

Motivation is an impulse that will cause a person to perform an act in order to achieve certain goals. Motivation comes from the word motive which means "encouragement" or stimulation or "driving forces" that exist in a person. According to Elliot et al. [3], motivation is defined as an internal condition that raises us to act, encouraged us to reach certain goals, and keep us interested in a particular activity.

According to Uno [4], motivation can be defined as an internal and external impetus in a person who indicated the presence; desires and interests; encouragement and needs; hopes and ideals; awards and honors. Motivation is something that makes a person act [5] states that motivation is the impact of the interaction of a person with the situation [6].

Motivation is a force, energy, or power, or a complex situation and readiness within the individual to move towards a certain goal, either consciously or unconsciously [12]. Motivation someone can be generated and grow through self-intrinsic-extrinsic and of the environment $[3,5]$. Significant intrinsic motivation as the desire of themselves to act in the absence of external stimuli $[3]$. Intrinsic motivation will be more profitable and provide regularity in learning. Extrinsic motivation is described as the motivation that comes from outside the individual and can not be controlled by the individual [5]. Elliott et al. [3], example with grades, prizes and / or awards are used to stimulate people's motivation.

Motivation in terms of processes, means of motivation can be stimulated by external factors, to induce motivation in students through the process of learning stimuli so as to achieve the desired objectives in. Motivation in terms of objectives, means the motivation is the stimulus target to be achieved. If one has a desire to learn a thing, then he will be motivated to achieve it.

\section{Organizational Performance}

According to Richard et al. [13] the performance of the organization is generated by organizations that include results (outcomes) that the financial performance such as profit, as measured by return on assets, return on investment and so on, the performance of the market such as the expansion of market share, and sales. Besides the return of shareholders a return of shareholders and increase the economy of shareholders.

In some areas of the organization's performance can also be measured by other things such as strategic planning, operations, finance, legal and organizational development. In developing the institution or organization is a necessity to survive in the competitive world climate.

The purpose of productivity associated with the development of that organization [14]. Small organizations that have a desire to continue to grow and become large. The growing organization in order to the development itself.

Measuring the performance of the organization according to the concept of PBM SIG (the performance-based management special interest group is to perform monitoring and reporting programs, and pay attention to objectives achieved. Performance is measured based on the activities of the program to run, products, and services produced. The effectiveness of the organization's achievement of performance should be able to answer questions

- $\quad$ how the project is implemented well

- the achievement of organizational goals

- the satisfaction of consumers who served

- $\quad$ the process must be controlled

- development organization

Besides Kaplan and Norton [15] the organization's performance should be measured in terms of concept not only financial but also from non-financial. Performance can be measured by productivity, quality, consistency and so on. On the other hand measure organizational performance outcomes, behavioral and normative level, education and concepts generated including management development [13].

\section{Research Methods}




\section{Research Design}

This research uses explanatory analysis approach. This means that each of the variables presented in the hypothesis will be observed by testing the causal relationship of independent variables on the dependent variable. Relationships between variables can be described in terms of the path analysis diagram as follows:

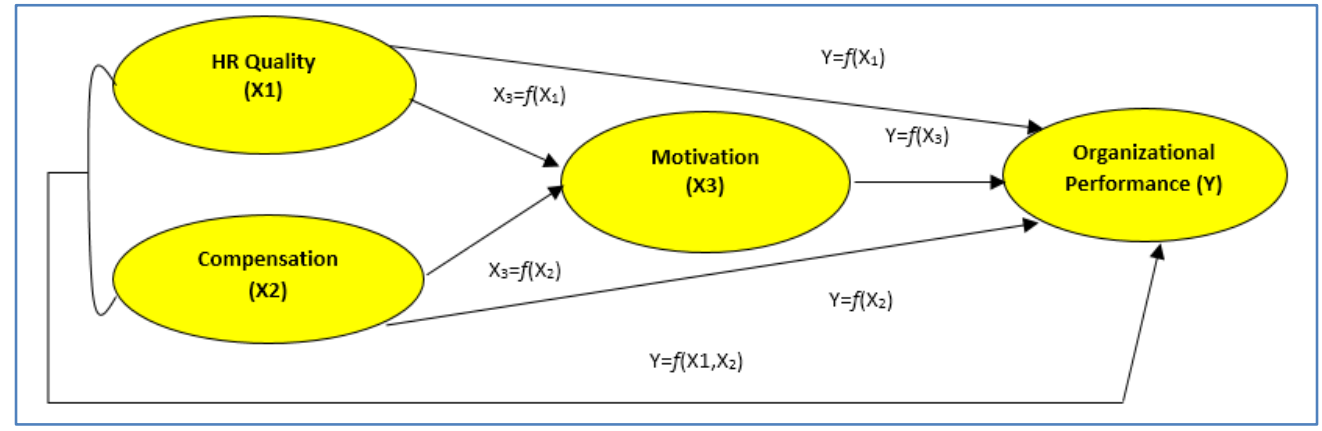

Fig-1: Overall Path Analysis

\section{Object of Research} Jakarta.

The study was conducted in the employee Located JI Gatot Subroto Army Hospital. Abdul Rahman Saleh No. 24, Central

\section{Population and Sample Research}

The population is a generalization region consisting of the objects/subjects that have a certain quantity and characteristics defined by the researchers to learn and then drawn conclusions [16]. Samples were towing the majority of the population to represent the entire population [17]. The sample used by the author in this study were employees The total number of employees as many as 133 people. The number of employees fully involved in this study. So that this sampling method saturated samples.

\section{Results AND Discussion}

\section{Impact of Human Resources Quality and Compensation on Organizational Performance}

Based on the results of data analysis using SPSS, it is known that the calculated F value of 10.054 and significance of 0.00 . This value is less than 0.05 . This means that the variable quality of human resources and compensation effect on organizational performance simultaneously. $\mathrm{R}$ squared value of $60.9 \%$ meaning that the variable quality of human resources and compensation effect on organizational performance by $60.9 \%$ while the rest influenced by other variables that are not incorporated into the model equations.

\section{Analysis Effect of Human Resources Quality on Organizational Performance}

The analysis results in the quality of human resources on the performance is partially known that the human resources quality coefficient of 0.515 . T value of 6.882 . The significant value of 0.00 . The significance value smaller than 0.05 . This means that the variable quality of human resources affects the organization's performance partially. $R$ squared value of 0.266 . This means that the effect quality of human resources on the performance and the remaining $26.6 \%$ is influenced by other variables that are not incorporated into the model equations.

\section{Effect Analysis of Compensation on Organizational Performance}

The analysis results in partial compensation to performance is known that the coefficient of 0.648 . T value of 9.733 . The significant value of 0.00 . The significance value smaller than 0.05 . This means that the compensation variables affect the performance of an organization partially. $\mathrm{R}$ squared value of 0.420 . This means that the effect of variable compensation to organizational performance amounted to $42.0 \%$ and the rest influenced by other variables not included in the model equations.

\section{Analysis of Effect of Motivation on Organizational Performance}

The analysis results on the performance of partial motivation are known that motivation coefficient of 0.862 . T value of 19.506. The significant value of 0.00 . The significance value smaller than 0.05 . This means that the motivation variable influence on organizational performance partially. $R$ squared value of 0.744 . This means that the motivation variable influence on organizational performance amounted to $74.4 \%$ and the rest influenced by other variables not included in the model equations.

Impact Analysis of HR Quality on Organizational Performance through Motivation of this sub-image.

Based on the partial path analysis above, it can be described as follows. The analysis is an analysis online with the structure 


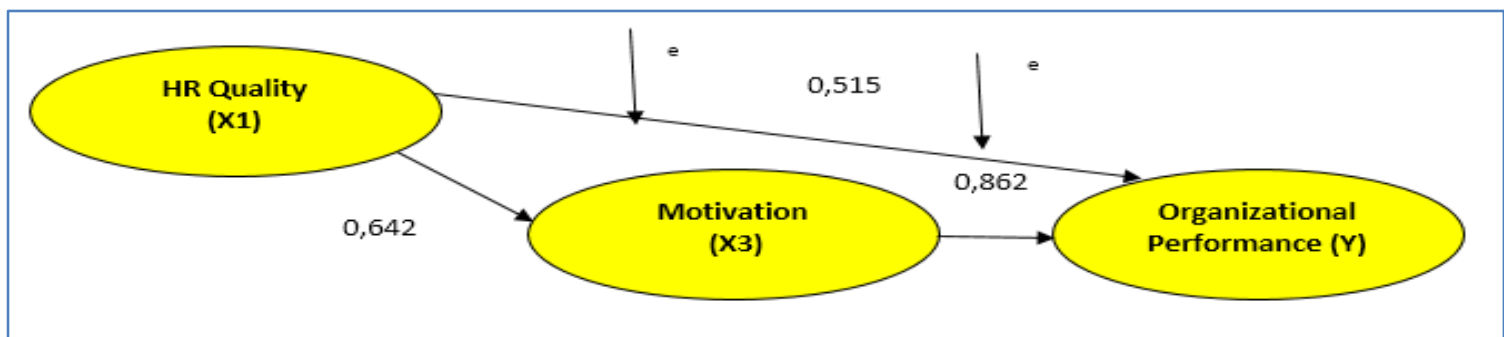

Fig-2: Analysis of the influence lines $\mathrm{X} 1$ to $\mathrm{Y}$ via $\mathrm{X} 3$

Based on Figure 2, it can be seen that the influence of the quality of human resources to organizational performance is 0.515. Influence on the performance quality of human resources through motivation is $0.642 \times 0.862=0.553$. In this case the indirect effect is greater than the direct effect so that it can be said that the work motivation as an intervening variable.

\section{Effect Analysis of Compensation on Organizational Performance through Motivation}

Based on the partial path analysis above, it can be described as follows. The analysis is an analysis online with the structure of this sub-image.

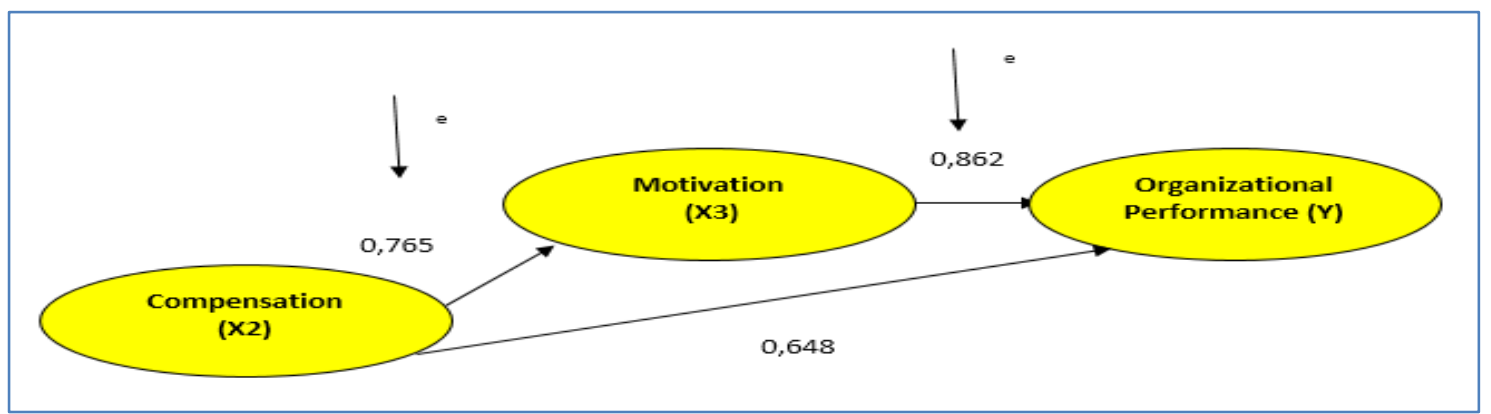

Fig-3: Analysis of the influence lines $X 2$ to $Y$ via X3

Based on Figure 3, it can be seen that the direct effect of compensation to organizational performance is 0.648 . While the effect of compensation to organizational performance through motivation is $0.765 \times 0.862=0.6594$. In this case smaller than the direct influence indirect influence so that it can be said that the work motivation as an intervening variable.

\section{Conclusions AND Suggestions Conclusion}

Variable quality of human resources and compensation effect on organizational performance simultaneously. $F$ value calculated at 10.054 and significance of 0.00 . This value is less than 0.05 . R squared value of $60.9 \%$ means that the variable quality of human resources and compensation effect on organizational performance by $60.9 \%$ while the rest influenced by other variables that are not incorporated into the model equations.

Variable quality of human resources affects the organization's performance partially. T value of 6.882 . The significant value of 0.00 . The significance value smaller than 0.05 . R squared value of 0.266 . This means that the effect quality of human resources on the performance remaining $26.6 \%$ is influenced by other variables that are not incorporated into the model equations.

Variable compensation effect on organizational performance partially. T value of 9.733 . The significant value of 0.00 . The significance value smaller than 0.05 . R squared value of 0.420 . This means that the effect of variable compensation to organizational performance amounted to $42.0 \%$ and the rest influenced by other variables not included in the model equations.

Motivation variable influence on organizational performance partially. T value of 19.506 . The significant value of 0.00 . The significance value smaller than 0.05 . $R$ squared value of 0.744 . This means that the motivation variable influence on organizational performance amounted to $74.4 \%$ and the rest influenced by other variables not included in the model equations.

The influence of the quality of human resources to organizational performance is .515 . Influence on the performance quality of human resources through motivation is $0.642 \times 0.862=0.553$. In this case the indirect effect is greater than the direct effect so that it can be said that the work motivation as an intervening variable. 
The direct effect of compensation to organizational performance is 0.648 . While the effect of compensation to organizational performance through motivation is $0.765 \times 0.862=0.6594$. In this case smaller than the direct influence indirect influence so that it can be said that the work motivation as an intervening variable.

\section{SUGGESTION}

Organizational performance needs to be improved by improving the quality of human resources that are used by the organization. Organizations need to enhance human resource capabilities finishing work, employee self-development, improve the physical quality and enhance mental quality. Improved performance of the organization also needs to be conducted with respect to compensation. Compensation awarded compensation needs to be evaluated both financially and non-financially. Employee motivation also needs to be improved with the needs of employee achievement, affiliation needs of employees, other needs such as the desire to achieve a goal or desire to become officers in the organization.

\section{REFERENCES}

1. MM, S. H. S. (1985). Manajemen sumber daya manusia I.

2. Arita, S., Pan, M., Hospital, J., \& Leung, P. (2013). The distributive economic impacts of Hawaii's commercial fishery: A SAM analysis. Fisheries research, 145, 82-89.

3. Elliott, S. N., \& Travers, J. F. (1996). Educational psychology: Effective teaching, effective learning. Madison, WI: Brown \& Benchmark.

4. Uno, H. B., \& Motivasi, T. (2011). Pengukurannya (Analisis di Bidang Pendidikan). Jakarta: PT Bumi Akasara.

5. Pritchard, M. P., Havitz, M. E., \& Howard, D. R. (1999). Analyzing the commitment-loyalty link in service contexts. Journal of the academy of marketing science, 27(3), 333.

6. Sondang, P. S. (2008). Manajemen Sumber Daya Manusia. Jakarta: Bumi Aksara.

7. Sedarmayanti. (2013). Manajemen Sumber Daya Manusia, Reformasi Birokrasi Manajemen Pegawai Negeri Sipil. Rafika Aditama, Bandung.

8. Hadari N. (2003). Manajemen Sumber Daya Manusia Untuk Bisnis yang Competitif, Gajah Mada University Press, Yogyakarta.

9. Ndraha, T. (1997). Budaya Organisasi. Jakarta: Rineka Cipta.

10. Malayu, H. S., \& Hasibuan, P. (2007). Manajemen Sumber Daya Manusia Dasar dan Kunci Keberhasilan. Jakarta: PT Toko Gunung Agung.

11. Notoatmodjo, S. (2009). Pengembangan Sumber Daya Manusia Cetakan Keempat. Jakarta: Penerbit Rineka Cipta.

12. Syamsuddin Makmun, A. (2003). Psikologi Pendidikan. Bandung: PT Rosda. Karya Remaja.

13. Daft, Richard, L. (2010). Manajemen Edisi Kelima Jilid Satu. Jakarta : Erlangga.

14. Shrestha, T.(1997). Metodologi IImu Pemerintahan. Jakarta: Rineka Cipta.

15. Kaplan, R. S., \& Norton, D. P. (1992). The balanced scorecard: measures that drive performance.

16. Sugiyono, P. D. (2013). Metode Penelitian Manajemen. Bandung: Alfabeta, CV.

17. Winarno, S. (2010). Pengantar Penelitian IImiah Dasar Metode Teknik. Bandung: Tarsito. 